\title{
Correction to: Biotic and abiotic controls on carbon storage in aggregates in calcareous alpine and prealpine grassland soils
}

\author{
Noelia Garcia-Franco ${ }^{1}(1) \cdot$ Roswitha Walter $^{2} \cdot$ Martin Wiesmeier $^{1,2} \cdot$ Luis Carlos Colocho Hurtarte $^{1}$. \\ Bernd Josef Berauer ${ }^{3} \cdot$ Vincent Buness $^{1} \cdot$ Marcus Zistl-Schlingmann ${ }^{4} \cdot$ Ralf Kiese $^{4} \cdot$ Michael Dannenmann $^{4}$. \\ Ingrid Kögel-Knabner ${ }^{1,5}$
}

Published online: 3 July 2021

(c) The Author(s) 2021

\section{Correction to: Biology and Fertility of Soils (2021) 57:203-218 https://doi.org/10.1007/s00374-020-01518-0}

The article "Biotic and abiotic controls on carbon storage in aggregates in calcareous alpine and prealpine grassland soils", written Noelia Garcia-Franco, Roswitha Walter, Martin Wiesmeier, Luis Carlos Colocho Hurtarte, Bernd Josef Berauer, Vincent Buness, Marcus Zistl-Schlingmann, Ralf Kiese, Michael Dannenmann and Ingrid Kögel-Knabner, was originally published Online First without Open Access. After publication in volume 57, issue 2, page 203-218 the author decided to opt for Open Choice and to make the article an Open Access publication. Therefore, the copyright of the article has been changed to () The Author(s) 2021 and the article is forthwith distributed under the terms of the Creative Commons Attribution 4.0 International License, which permits use, sharing, adaptation, distribution and reproduction in any medium or format, as long as you give appropriate credit to the original author(s) and the source,

The online version of the original article can be found at https:// doi.org/10.1007/s00374-020-01518-0

Noelia Garcia-Franco

noelia.garcia-franco@wzw.tum.de

1 Chair of Soil Science, TUMSchool of Life Sciences Weihenstephan, Technical University of Munich, Freising, Germany

2 Bavarian State Research Center for Agriculture, Freising, Germany

3 Department of Disturbance Ecology, University of Bayreuth, Bayreuth, Germany

4 Karlsruhe Institute of Technology, Institute of Meteorology and Climate Research I (IMK-IFU), Garmisch-Partenkirchen, Germany

5 Institute for Advanced Study, Technical University Munich, Garching, Germany provide a link to the Creative Commons licence, and indicate if changes were made. The images or other third party material in this article are included in the article's Creative Commons licence, unless indicated otherwise in a credit line to the material. If material is not included in the article's Creative Commons licence and your intended use is not permitted by statutory regulation or exceeds the permitted use, you will need to obtain permission directly from the copyright holder. To view a copy of this licence, visit http:// creativecommons.org/licenses/by/4.0.

Open Access This article is licensed under a Creative Commons Attribution 4.0 International License, which permits use, sharing, adaptation, distribution and reproduction in any medium or format, as long as you give appropriate credit to the original author(s) and the source, provide a link to the Creative Commons licence, and indicate if changes were made. The images or other third party material in this article are included in the article's Creative Commons licence, unless indicated otherwise in a credit line to the material. If material is not included in the article's Creative Commons licence and your intended use is not permitted by statutory regulation or exceeds the permitted use, you will need to obtain permission directly from the copyright holder. To view a copy of this licence, visit http://creativecommons.org/licenses/by/4.0/.

Publisher's note Springer Nature remains neutral with regard to jurisdictional claims in published maps and institutional affiliations. 